\title{
Anti-tubulin-alpha-1c antibody as a marker of value in Behçet syndrome
}

\author{
Mariam Maged Amin ${ }^{1} \cdot$ Osama M. Abdel Latif ${ }^{1}$
}

Received: 6 May 2021 / Revised: 15 December 2021 / Accepted: 16 December 2021 / Published online: 7 February 2022

(c) The Author(s) 2022

\begin{abstract} Anti-endothelial cell antibodies (AECA) and anti-tubulin-alpha-1c antibodies were performed for all participants. 22.300 , with sensitivity and specificity of $100 \%$ and $96.7 \%$ respectively. and $96.7 \%$ specificity.

Key Points

- There is lack of specific laboratory, radiological, or histological diagnostics for Behcet syndrome.

- We aimed to evaluate the significance of tubulin- $\alpha$-1c autoantibody in diagnosis of Behcet syndrome.

- There is elevation of tubulin- $\alpha-1$ c autoantibody with sensitivity and specificity of $100 \%$ and $96.7 \%$, respectively.
\end{abstract}

Background Behçet's syndrome (BS) is a multi-systemic vasculitis characterized by recurrent oral ulcers, genital ulcers, ocular lesions, and other systemic manifestations. As there is no laboratory diagnostics of BS, the diagnosis is mainly clinical. Objective To investigate the utility of the autoantibody against tubulin- $\alpha-1 \mathrm{c}$ in diagnosis of BS and its clinical significance. Methods Sixty BS patients and sixty healthy controls were enrolled in this study. We assessed all patients by Behçet disease current activity form (BDCAF), routine laboratory investigations, and immunological markers (ANA, anti-DNA, ANCA).

Results Regarding duration of illness, Birmingham Vasculitis Activity Score (BVAS), and BDCAF, the mean value was $4.77 \pm 4.239,19.80 \pm 10.020$, and $9.52 \pm 5.476$, respectively. On comparing laboratory investigations, there was only significant increase in anti-tubulin-alpha-1c antibody in BS patients compared to healthy controls. Regarding AECA, there was no any significant correlation except with CRP. Anti-tubulin-alpha-1c detected significant direct correlation with the presence of posterior uveitis, panuveitis, and venous thrombosis as well as BVAS, C4, and protein/creatinine ratio. Regarding diagnostic performance of both AECA and anti-tubulin-alpha-1c, the cutoff value of AECA for diagnosis was 27.250, with sensitivity and specificity of $93.3 \%$ and $96.7 \%$, respectively. The cutoff value of the anti-tubulin-alpha-1c for diagnosis was

Conclusion Anti-tubulin- $\alpha-1 \mathrm{c}$ antibodies are of diagnostic value in BS and are indicative of activity with $100 \%$ sensitivity

Keywords Anti-endothelial cell antibodies $\cdot$ Behcet syndrome $\cdot$ Tubulin- $\alpha-1 \mathrm{c}$ antibodies $\cdot$ Vasculitis

\section{Introduction}

Behçet's syndrome (BS) is a syndrome of relapsing and remitting pattern in which most of its clinical presentations are due to blood vessel vasculitis (small, medium, or large sized) of both the arterial and venous system. Heterogeneity is a dominant feature of BS making its diagnosis and treatment

Mariam Maged Amin

mariamaged@yahoo.com; mariammaged@med.asu.edu.eg

1 Department of Internal Medicine, Clinical Immunology and Allergy, Faculty of Medicine, Ain Shams University, Ramsis St., Abbasseya, Beside El Nour Mosque, 11566 Cairo, Egypt challenging [1,2]. Globally, it affects mostly the Eurasian populations along the ancient trading route which extends from eastern Asia to the Mediterranean basin. Egypt is considered a high incidence for being a Mediterranean country [3] with a prevalence of 3.6/100,000 [4].

BS is characterized by a triad of recurrent oral ulcers, genital ulcers, and ocular lesions with/without other clinical dermatological, cardiovascular, gastrointestinal, and neurological symptoms [5]. Due to the lack of specific laboratory, radiological, or histological diagnostics for BS, the diagnosis is mainly clinical. Different diagnostic criteria were proposed [6, 7], and the revised International Criteria for Behçet's Disease (ICBD) 2010 are the most commonly used and validated on different ethnic groups [8]. 
The etiology of BS remains unknown. Several genetic factors and immune-mediated mechanisms might contribute. However, unlike other autoimmune diseases, BS cannot be diagnosed using any autoantigens as in other autoimmune diseases. The lack of reliable diagnostic markers delays improvement of treatment in BS $[9,10]$.

It is well established that endothelial cells are involved in vasculitis [11-13]. Hence, IgG autoantibodies to antigens expressed on endothelial cells have been detected in a variety of autoimmune diseases $[14,15]$. One of these is a circulating immunoglobulin, called anti-endothelial cell antibody (AECA), detected in BS. However, no evidence exists if these antibodies can influence clinical presentation and/or activity of BS or not $[14,16,17]$.

Though AECA can detect vascular damage of BS [18-20], its presence in other systemic vasculitis is quite high, making accurate diagnosis demanding. Hence, identification of novel markers for BS diagnosis is required [12, 13, 21]. For this, a diversity of autoantigens have been studied in BS, including vascular proteins such as alpha-enolase [19], organ or tissue original proteins such as alpha-tropomyosin, and selenium-binding protein $[18,20,22]$, however with limited sensitivity and specificity [23].

Microtubules are cytoskeletal basic structural components of vascular cells that are assembled from $\alpha-/ \beta$-tubulin heterodimers [24]. The tubulin superfamily includes six distinct families, and they exist in several isotype forms. Tubulin- $\alpha-1 \mathrm{c}$, also known as tubulin-alpha- 6 , is one of the alpha-tubulin family members [25]. The expression of tubulin- $\alpha-1 \mathrm{c}$ among different cell types is still elusive [24]. Alpha-tubulin has been identified as an autoantigen in patients with chronic allograft rejection [26, 27]. However, the clinical relevance of $\alpha$-tubulin autoantibodies in autoimmune diseases is still unclear. Hence, we aimed to evaluate the significance of autoantibody against tubulin- $\alpha-1 \mathrm{c}$, as a novel diagnostic marker in BS, and its possible link with BS activity and phenotypes.

\section{Methodology}

\section{Study participants}

A case-control study was conducted on sixty patients diagnosed to have Behçet syndrome (BS) according to the International Study Group for Behçet's Disease classification criteria [28]. They were recruited from the Immunology Ward and Clinic of Ain Shams University Hospital. Another group of matched sixty healthy individuals was enrolled as control group. Patients with any other autoimmune diseases including juvenile BS, diabetes mellitus, cardiac diseases, thyroid dysfunction, and hepatic or renal dysfunction; smokers; those with history of infection ( $<3$ months); or patients receiving medications that act on endothelial cells (statins, angiotensin-converting enzyme inhibitors) were excluded from the study. The study was approved by the research ethical committee of Ain Shams University. A written informed consent was obtained from all participants.

\section{Study design}

Detailed clinical history (including duration of illness; family history; presence of oral ulcers, genital ulcers, erythema nodosum or acneiform eruptions, arthralgia or arthritis, and vascular, pulmonary, gastrointestinal, neurological, and ophthalmic manifestations) and examination were applied for all recruited patients with assessment of disease activity and Birmingham Vasculitis Activity Score. We assessed all patients with the routine laboratory investigations (ESR, CRP, kidney and liver functions, complete blood picture, urine analysis with $\mathrm{pr} / \mathrm{cr}$ ratio, $\mathrm{C} 3, \mathrm{C} 4$, eGFR) in addition to the immunological markers (ANA, anti-DNA, ANCA). AECA and anti-tubulin-alpha-1c were withdrawn for all participants. Some radiological assessment was done when needed as arterial and venous duplex. Ophthalmological assessment was done for all participants.

\section{Pathergy test}

It was performed by inserting a small 5-mm needle obliquely into the patient's flexor aspect into the dermis forearm skin under complete sterile condition and without injecting saline of the forearm. The reaction is considered positive if either a papule, a pustule, or an ulcer forms at the puncture site within $48 \mathrm{~h}$ [29].

\section{Behçet syndrome activity}

We assessed BS activity by the Behçet Disease Current Activity Form (BDCAF) score [30]. It includes presence or absence of new headache, mouth ulcers, genital ulcers, skin lesions (pustules or erythema nodosum), joint involvement (arthralgia or arthritis), gastrointestinal symptoms (nausea/vomiting/abdominal pain or diarrhea with altered/ frank blood), eye involvement (red or painful eye, blurred/ reduced vision), neurological involvement (difficulty with speech or hearing, blurring of/double vision, weakness/loss of feeling of arm or leg, and loss of balance), and major vessel involvement (chest pain, breathlessness, hemoptysis, and pain/swelling/discoloration of the face or arm or leg) over the last 4 weeks. The BDCAF score ranges from 0 to 12 , and accordingly, the patients were divided into two groups: a higher disease activity group with a score equals to or more than 4 out of 12 and a lower disease activity group with a score less than 4 . 


\section{Birmingham Vasculitis Activity Score (BVAS)}

We calculated BVAS at time of diagnosis to assess vascular activity. The weighted score is based on symptoms and signs in nine separate organ systems. Score ranges from 0 to 63 [31].

\section{Biochemical analysis for anti-tubulin-alpha-1c antibody}

Samples were analyzed for anti-tubulin- $\alpha-1 \mathrm{c}$ autoantibodies by enzyme-linked immunosorbent assay. Ninety-six-well plates were coated with $10 \mu \mathrm{g} / \mathrm{mL}$ recombinant tubulin- $\alpha-1 \mathrm{c}$ protein in $0.25 \%$ phosphate-buffered saline (PBS). Samples were then diluted at 1:100 with PBS-T containing $1 \%$ BSA. All samples were incubated for $1.5 \mathrm{~h}$ at $37^{\circ} \mathrm{C}$. Then, 100 $\mu \mathrm{L}$ of goat anti-human IgG, diluted at 1:5000 in PBS-T, was added to each well and incubated for $30 \mathrm{~min}$ at $37{ }^{\circ} \mathrm{C}$. The antibodies were then detected with o-phenylenediamine after washing with PBS-T. The reaction was stopped by adding $100 \mu \mathrm{L}$ of $2 \mathrm{M}$ sulfuric acid in each well.

\section{Statistical methodology}

Data was revised, coded, tabulated, and introduced to a PC using Statistical Package for Social Science (SPSS 20 for windows). Checking for quality of data and data entry was performed. Data was presented and suitable analysis was done according to the type of data. Descriptive statistics and mean \pm standard deviation $( \pm S D)$ were used for parametric numerical data, while frequency and percentage were used for qualitative data. For analytical statistics, we used Student's $t$ test to assess the statistical significance of the difference between two study group means. The chi-square test was used to examine the relationship between two qualitative variables. Fisher's exact test was used to examine the relationship between two qualitative variables when the expected count is less than 5 in more than $20 \%$ of cells. The Pearson correlation was used to measure the strengths of association between two quantitative variables.

\section{Results}

Demographic characteristics and manifestations of both studied groups are shown in Table 1. Both studied groups were comparable for age and gender. Mean age of the patients with BS and the healthy controls was $30.3 \pm 5.8$ and $28.9 \pm 6.1$ years, respectively. Mean disease duration of BS was $4.77 \pm 4.239$ years. Regarding BVAS score and Behcet activity score of patients, the mean value was $19.80 \pm 10.020$ and $9.52 \pm 5.476$, respectively. Figure 1 shows the prevalence of different presentations among BS patients. Fifty-five percent of BS patients had high disease activity index, and $45 \%$ had low disease activity index.

On comparing laboratory investigations between the two studied groups, there was a significant increase in serum levels of BUN, anti-tubulin-alpha-1c, and ESR (Table 2) and significant decrease in eGFR and C3 in BS patients compared to healthy controls. Urine analysis in BS patients detected significant increase in pus cells, p/c, casts, and albuminuria compared to healthy controls as shown in Table 2 .

Regarding correlations of AECA with different clinical presentations among cases, there was no significant correlation among any except with venous thrombosis ( $p$ value 0.024 ), while the correlations of anti-tubulin-alpha$1 \mathrm{c}$ with different disease presentations among cases show significant direct correlation with posterior uveitis, panuveitis, and venous thrombosis with $p$ values of 0.023 , 0.034 , and 0.009 , respectively.
Table 1 Demographic characteristics and manifestations of both studied groups

\begin{tabular}{lllll}
\hline & & \multicolumn{2}{l}{ Study groups } & \multirow{2}{*}{$p$ value } \\
\cline { 3 - 4 } & & Cases & Controls & \\
\hline Age in years (mean \pm SD) & & $30.3 \pm 5.8$ & $28.9 \pm 6.1$ & 0.203 \\
Gender & Males & $31(51.7 \%)$ & $31(51.7 \%)$ & 0.897 \\
& Females & $29(48.3 \%)$ & $29(48.3 \%)$ & \\
Smoking & Non-smoker & $43(71.7 \%)$ & $44(73.3 \%)$ & 0.838 \\
& Smoker & $17(28.3 \%)$ & $16(26.7 \%$ & \\
Contraception & None & $51(85.0 \%)$ & $49(81.7 \%)$ & 0.829 \\
& IUD & $7(11.7 \%)$ & $7(11.7 \%)$ & \\
Arthralgia & OCP & $2(3.3 \%)$ & $4(6.7 \%)$ & \\
Oral ulcers & & $41(68.3 \%)$ & $35(58.3 \%)$ & 0.256 \\
HTN & & $57(95.0 \%)$ & $18(30.0 \%)$ & $<0.001 *$ \\
Pathergy test & & $23(38.3 \%)$ & $23(38.3 \%)$ & 0.897 \\
\hline
\end{tabular}

*Significant 
Fig. 1 Prevalence of Behçet syndrome (BS) manifestations among patients (60 cases)

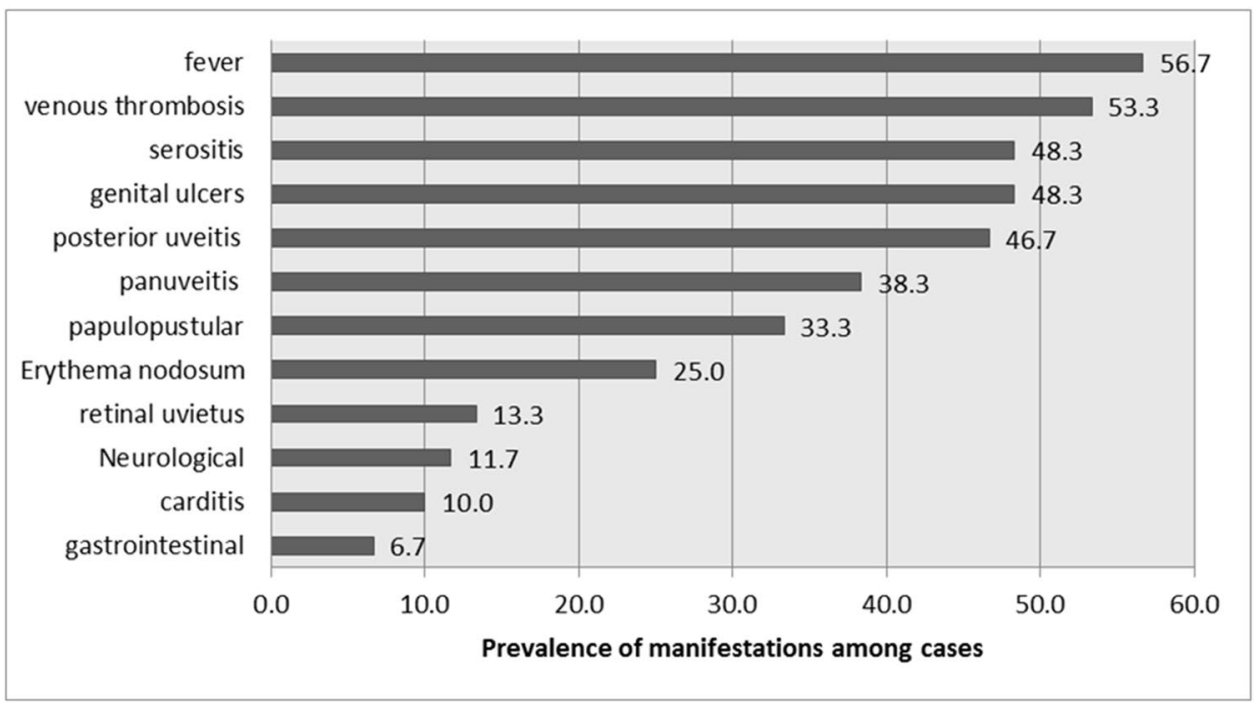

Table 2 Laboratory data of both studied groups

\begin{tabular}{lccr}
\hline & Cases & \multicolumn{1}{l}{ Controls } & $p$ value \\
& Mean \pm SD & Mean \pm SD & \\
\hline White blood cells & $7.1 \pm 3.6$ & $7.1 \pm 3.6$ & 1.000 \\
Hemoglobin & $10.1 \pm 1.8$ & $12.9 \pm 1.1$ & 1.000 \\
Platelets & $217.7 \pm 108.3$ & $231.5 \pm 70.5$ & 0.413 \\
Blood urea nitrogen (BUN) & $26.1 \pm 6.5$ & $16.4 \pm 5.0$ & $<0.001^{*}$ \\
Creatinine & $0.9 \pm 0.3$ & $1.0 \pm 0.8$ & 0.460 \\
C3 & $89.6 \pm 38.1$ & $128.9 \pm 26.8$ & $0.000^{*}$ \\
C4 & $26.4 \pm 12.0$ & $28.4 \pm 10.6$ & 0.331 \\
Erythrocyte sedimentation & $86.8 \pm 42.6$ & $28.9 \pm 24.4$ & $0.000^{*}$ \\
$\quad$ rate & & & \\
C-reactive protein & $13.7 \pm 18.0$ & $11.4 \pm 9.8$ & 0.380 \\
Pus cells & $6.1 \pm 5.9$ & $4.0 \pm 2.7$ & $0.013^{*}$ \\
Albumin & $0.3 \pm 0.4$ & $0.0 \pm 0.0$ & $0.000^{*}$ \\
Casts & $0.1 \pm 0.3$ & $0.0 \pm 0.0$ & $0.022^{*}$ \\
Protein/creatinine ratio & $5.5 \pm 10.5$ & $2.0 \pm 2.7$ & $0.015^{*}$ \\
Anti-endothelial cell anti- & $44.7 \pm 12.6$ & $41.0 \pm 8.8$ & 0.064 \\
$\quad$ bodies & & & \\
Anti-tubulin-alpha-1c & $76.9 \pm 21.7$ & $38.0 \pm 9.9$ & $0.000^{*}$ \\
$\quad$ antibody & & & \\
\hline
\end{tabular}

*Significant

On analyzing correlations of AECA with different disease parameters among cases, we found no significant correlation among any except with CRP with $p$ value 0.032 as shown in Table 3. Table 4 shows the correlations of antitubulin-alpha-1c with different disease parameters among cases in which there is significant direct correlation with BVAS, C4, and $\mathrm{p} / \mathrm{c}$.

On analyzing the diagnostic performance of both AECA and anti-tubulin-alpha-1c, ROC analysis detected that the cutoff value of the AECA for diagnosis was 27.250, with sensitivity and specificity of $93.3 \%$ and $96.7 \%$, respectively, while the cutoff value of anti-tubulin-alpha- $1 \mathrm{c}$ for diagnosis was 22.300 , with sensitivity and specificity of $100 \%$ and 96.7\%, respectively, as shown in Fig. 2.

\section{Discussion}

Behçet's syndrome (BS), as an autoimmune vasculitis with multi-organ involvement, has no specific laboratory investigations for diagnosis. There may be increase in inflammatory markers as C-reactive protein and erythrocyte sedimentation rate during activity [32]. Detection of autoantibodies is the cornerstone of various autoimmune diseases' diagnosis. However, BS lacks any specific autoantibodies. Hence, it is essential to detect autoantibodies as diagnostic biomarkers. Several potential autoantigens were detected in circulating immune complexes of BS patients which were involved in pathophysiological abnormalities of BS including immune response, cell structure integrity, and coagulation cascade [33].

Previous studies detected that anti-endothelial cell autoantibody (AECA) has contributed to vascular damage in BS [17, 34, 35]. However, AECA positivity percentages detected were low in different BS studies, which were $13.1 \%, 26 \%$, and $47.5 \%$ in Turkish, Spanish, and Chinese patients with BS, respectively. In addition, AECA was also detected in healthy participants, so lacking its sensitivity and specificity in BS $[15,35]$. Elevation of anti-tubulin autoantibodies is attributed to autoimmune reactions to the patient's own tubulin. However, specific autoantibodies against $\alpha$-tubulin, one of the tubulin molecular members, were only observed in patients with chronic allograft rejection after lung transplantation in some studies [36, 37], and its prevalence and clinical significance have not been 
Table 3 Correlations of anti-endothelial cell antibodies (AECA) with disease duration, Behçet syndrome (BS) activity, Birmingham Vasculitis Activity Score (BVAS), and laboratory data among cases

\begin{tabular}{|c|c|c|}
\hline & & AECA \\
\hline \multirow[t]{2}{*}{ Disease duration } & Pearson correlation & 0.035 \\
\hline & $p$ value & 0.789 \\
\hline \multirow[t]{2}{*}{ BVAS score } & Pearson correlation & 0.141 \\
\hline & $p$ value & 0.282 \\
\hline \multirow[t]{2}{*}{ Behcet activity score } & Pearson correlation & 0.091 \\
\hline & $p$ value & 0.490 \\
\hline \multirow[t]{2}{*}{ White blood cells } & Pearson correlation & -0.159 \\
\hline & $p$ value & 0.224 \\
\hline \multirow[t]{2}{*}{ Hemoglobin } & Pearson correlation & -0.069 \\
\hline & $p$ value & 0.600 \\
\hline \multirow[t]{2}{*}{ Platelets } & Pearson correlation & 0.164 \\
\hline & $p$ value & 0.211 \\
\hline \multirow[t]{2}{*}{ Blood urea nitrogen } & Pearson correlation & 0.207 \\
\hline & $p$ value & 0.113 \\
\hline \multirow[t]{2}{*}{ Creatinine } & Pearson correlation & -0.132 \\
\hline & $p$ value & 0.316 \\
\hline \multirow[t]{2}{*}{ ANA } & Pearson correlation & 0.161 \\
\hline & $p$ value & 0.220 \\
\hline \multirow[t]{2}{*}{ Anti-DNA } & Pearson correlation & 0.041 \\
\hline & $p$ value & 0.757 \\
\hline \multirow[t]{2}{*}{ ANCA } & Pearson correlation & 0.088 \\
\hline & $p$ value & 0.506 \\
\hline \multirow[t]{2}{*}{$\mathrm{C} 3$} & Pearson correlation & 0.020 \\
\hline & $p$ value & 0.882 \\
\hline \multirow[t]{2}{*}{$\mathrm{C} 4$} & Pearson correlation & -0.134 \\
\hline & $p$ value & 0.306 \\
\hline \multirow[t]{2}{*}{ Erythrocyte sedimentation rate } & Pearson correlation & 0.054 \\
\hline & $p$ value & 0.683 \\
\hline \multirow[t]{2}{*}{ C-reactive protein } & Pearson correlation & $277(*)$ \\
\hline & $p$ value & 0.032 \\
\hline \multirow[t]{2}{*}{ Pus cells } & Pearson correlation & -0.024 \\
\hline & $p$ value & 0.856 \\
\hline \multirow[t]{2}{*}{ Albumin } & Pearson correlation & 0.170 \\
\hline & $p$ value & 0.194 \\
\hline \multirow[t]{2}{*}{ Casts } & Pearson correlation & -0.032 \\
\hline & $p$ value & 0.808 \\
\hline \multirow[t]{2}{*}{ Protein/creatinine ratio } & Pearson correlation & -0.028 \\
\hline & $p$ value & 0.829 \\
\hline
\end{tabular}

*Significant correlation

determined yet in autoimmune diseases. To our knowledge, few studies had assessed this. Hence, we aimed to evaluate the significance of the autoantibody against tubulin- $\alpha-1 \mathrm{c}$ in BS.

Our study was conducted on sixty patients diagnosed to have BS and sixty healthy individuals who served as a control group. Both groups were comparable for age and gender. From the sixty BS patients, 55\% were with high disease activity score and $45 \%$ with low disease activity score. On comparing laboratory investigations, there was a significant increase in anti-tubulin-alpha-1c and ESR with significant decrease of $\mathrm{C} 3$ in patients compared to control. Urine analysis in cases detected significant increase in pus cells, p/c, casts, and albuminuria compared to healthy controls as expected. This is consistent with Cheng et al. (2018) who confirmed that tubulin- $\alpha-1 \mathrm{c}$ was significantly increased in 44 patients with BS than those with other autoimmune diseases and healthy controls. However, our study included only patients with BS and healthy controls [33].

Natural autoantibodies to tubulin, the basic unit of microtubules, are present in healthy humans [38] in low titers [39]. However, elevated levels of serum anti-tubulin autoantibodies have been reported to be associated with organ-specific autoimmune diseases as Graves' disease [40]. Tubulins are involved in the maintenance of cytoskeleton including both the cellular structure and intracellular movement [40]. It was postulated that tubulin- $\alpha-1 \mathrm{c}$ might also stimulate the expression of vascular endothelial growth factor and damage the endothelial cells resulting in vasculitis and thrombosis [41].

In the present study, there was non-statistically significant increase in serum AECA in BS patients compared to healthy controls. This is in contrast to Zheng et al. (2005) who studied AECA in BS and other autoimmune diseases and detected that AECA was found more frequently in patients with BS, especially with increased disease activity, and concluded that it can be used in monitoring disease activity and effect of therapy. This contrast can be explained by the fact that Zeng and collages examined the level of AECA at the activity period of disease compared to the controlled period. However, $55 \%$ of our patients had high disease activity index, and $45 \%$ were with low disease activity index. Unfortunately, AECA could also be found in other systemic vasculitis and SLE [35].

Endothelial cell dysfunction [34] and vasculitis [42] are major pathological findings in BS. Although the etio-pathogenesis of the BS is still unknown, anti-endothelial cell antibodies (AECAs) may be involved in the pathogenesis of vascular injury which is the main cause of autoimmune diseases [43]. But in the current study, non-significant increase was detected in BS patients, and this may be related to AECA positivity in healthy controls, making its sensitivity and specificity for diagnosis of BS very challenging $[15,35]$

On analyzing correlations of AECA with different disease presentations among cases, there was non-significant correlation among any except with venous thrombosis ( $p$ value 0.024 ), while regarding correlations of anti-tubulinalpha-1c with different disease presentations among cases, there is significant direct correlation with posterior uveitis, panuveitis, and venous thrombosis with $p$ values of 0.023 , 0.034 , and 0.009 , respectively. In line with ours, Chen and 
Table 4 Correlations of antitubulin-alpha-1c with disease duration, Behçet syndrome (BS) activity, Birmingham Vasculitis Activity Score (BVAS), and laboratory data among cases

\begin{tabular}{|c|c|c|}
\hline & & Anti-tubulin-alpha-1c \\
\hline \multirow[t]{2}{*}{ Disease duration } & Pearson correlation & 0.012 \\
\hline & $p$ value & 0.930 \\
\hline \multirow[t]{2}{*}{ BVAS score } & Pearson correlation & 0.198 \\
\hline & $p$ value & 0.129 \\
\hline \multirow[t]{2}{*}{ Behcet activity score } & Pearson correlation & $.385(* *)$ \\
\hline & $p$ value & 0.002 \\
\hline \multirow[t]{2}{*}{ White blood cells } & Pearson correlation & 0.245 \\
\hline & $p$ value & 0.059 \\
\hline \multirow[t]{2}{*}{ Hemoglobin } & Pearson correlation & 0.017 \\
\hline & $p$ value & 0.897 \\
\hline \multirow[t]{2}{*}{ Platelets } & Pearson correlation & 0.140 \\
\hline & $p$ value & 0.286 \\
\hline \multirow[t]{2}{*}{ Blood urea nitrogen } & Pearson correlation & 0.200 \\
\hline & $p$ value & 0.126 \\
\hline \multirow[t]{2}{*}{ Creatinine } & Pearson correlation & -0.171 \\
\hline & $p$ value & 0.193 \\
\hline \multirow[t]{2}{*}{ ANA } & Pearson correlation & 0.138 \\
\hline & $p$ value & 0.294 \\
\hline \multirow[t]{2}{*}{ Anti-DNA } & Pearson correlation & -0.114 \\
\hline & $p$ value & 0.388 \\
\hline \multirow[t]{2}{*}{ ANCA } & Pearson correlation & -0.047 \\
\hline & $p$ value & 0.721 \\
\hline \multirow[t]{2}{*}{$\mathrm{C} 3$} & Pearson correlation & -0.082 \\
\hline & $p$ value & 0.535 \\
\hline \multirow[t]{2}{*}{$\mathrm{C} 4$} & Pearson correlation & $-.266(*)$ \\
\hline & $p$ value & 0.040 \\
\hline \multirow[t]{2}{*}{ Erythrocyte sedimentation rate } & Pearson correlation & 0.235 \\
\hline & $p$ value & 0.070 \\
\hline \multirow[t]{2}{*}{ C-reactive protein } & Pearson correlation & 0.103 \\
\hline & $p$ value & 0.434 \\
\hline \multirow[t]{2}{*}{ Pus cells } & Pearson correlation & -0.191 \\
\hline & $p$ value & 0.144 \\
\hline \multirow[t]{2}{*}{ Albumin } & Pearson correlation & 0.180 \\
\hline & $p$ value & 0.169 \\
\hline \multirow[t]{2}{*}{ Casts } & Pearson correlation & 0.046 \\
\hline & $p$ value & 0.726 \\
\hline \multirow[t]{2}{*}{ Protein/creatinine ratio } & Pearson correlation & $.275(*)$ \\
\hline & $p$ value & 0.033 \\
\hline
\end{tabular}

* Significant correlation

**Highly significant correlation colleagues detected that anti-tubulin- $\alpha-1 \mathrm{c}$ was associated with complications of deep venous thrombosis and erythema nodosum in BD [33]. However in ours, there is no association with any dermatological but with ophthalmological and vascular complications.

Regarding correlations of AECA with different parameters among cases, there was non-significant correlation except of CRP with $p$ value 0.032 , while regarding correlations of anti-tubulin-alpha-1c among cases, there is significant direct correlation with BVAS, C4, and p/c. In harmony with ours, Cheng et al. (2018) showed that antitubulin- $\alpha-1 \mathrm{c}$ autoantibodies were significantly positively correlated with BS disease activity but also with inflammatory markers ESR and CRP.

To the best of our knowledge, ROC curve for both AECA and anti-tubulin-alpha-1c in BS was done for the first time 
Fig. 2 ROC curve for diagnostic performance of anti-endothelial cell antibodies (AECA) and anti-tubulin-alpha-1c

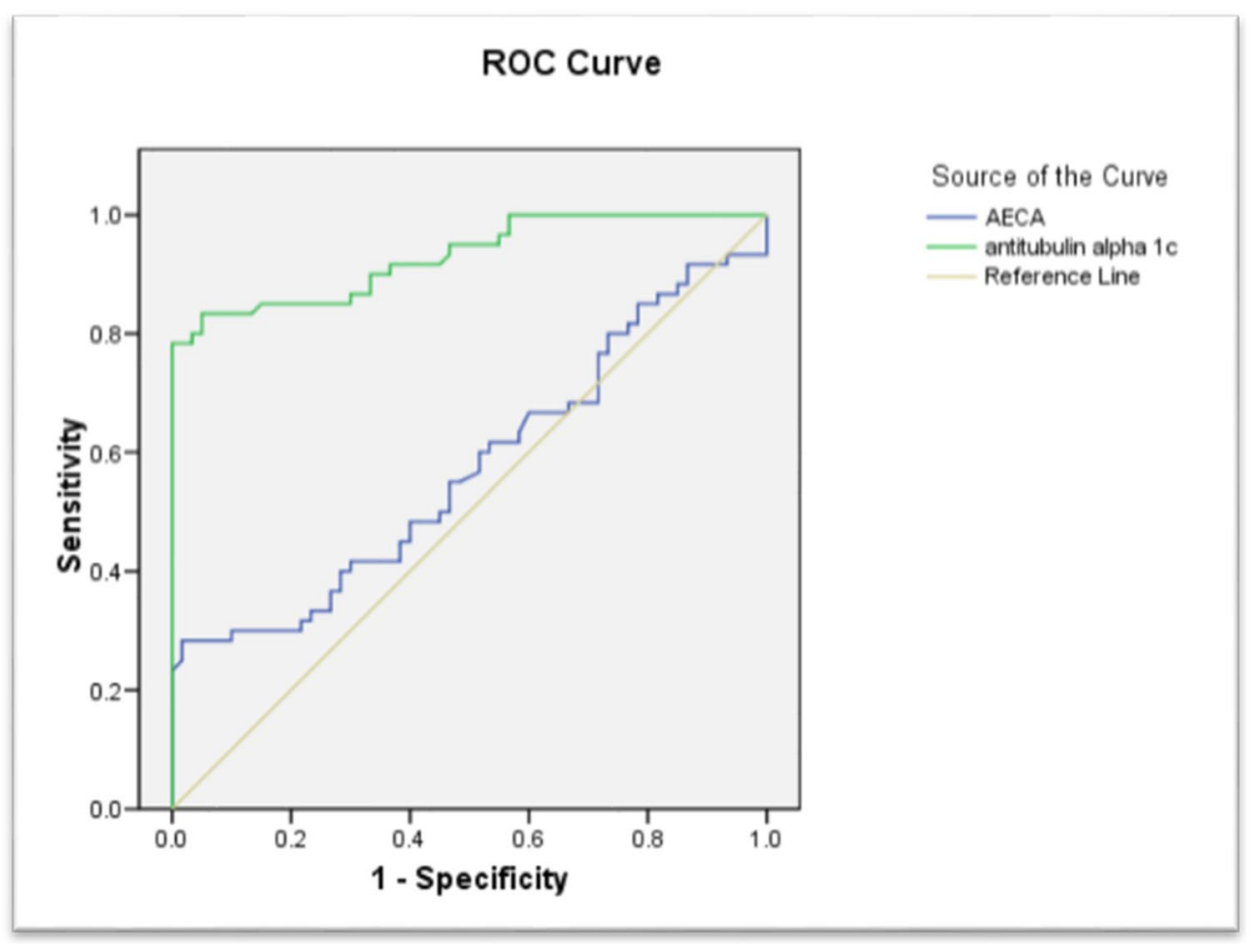

in the current study. Regarding the diagnostic performance of both AECA and anti-tubulin-alpha-1c, the cutoff value of the AECA for diagnosis was 27.250, with sensitivity and specificity of $93.3 \%$ and $96.7 \%$, respectively, while the cutoff value of the anti-tubulin-alpha-1c for diagnosis was 22.300 , with sensitivity and specificity of $100 \%$ and $96.7 \%$, respectively.

Previous research reported that immune complex deposition, which is formed by vascular autoantigens such as histones, ribosomes, fibronectin, and their autoantibodies, was able to induce exacerbated local inflammation within the vascular endothelium. Anti-tubulin- $\alpha-1 \mathrm{c}$ might bind to its antigen on vascular cells and induce inflammatory response and exacerbate tissue damage $[44,45]$. However, the exact role of the pathogenesis of anti-tubulin- $\alpha-1 \mathrm{c}$ in BS is still to be determined by further research, to identify the pathogenic roles of anti-tubulin- $\alpha-1 \mathrm{c}$ in BS.

\section{Conclusion}

Identification of anti-tubulin- $\alpha-1 \mathrm{c}$ antibodies as a novel biomarker for BS diagnosis may be promising for better targeting therapy. Elevation of serum tubulin- $\alpha$-1c autoantibody was detected in BS with sensitivity and specificity of $100 \%$ and $96.7 \%$, respectively. The anti-tubulin- $\alpha-1 \mathrm{c}$ autoantibody was positively correlated with venous thrombosis, uveitis, and disease activity in BS, which indicated liability of its involvement in the vascular pathogenesis of BS. Larger cohort studies for exploration of the exact roles of tubulin$\alpha-1 c$ and its autoantibodies are required.

Supplementary Information The online version contains supplementary material available at https://doi.org/10.1007/s10067-021-06025-7.

Author contribution The authors contributed equally to the conception and design of the work; the acquisition, analysis, and interpretation of data; and drafting, revising, and final approval of the manuscript.

Funding Open access funding provided by The Science, Technology \& Innovation Funding Authority (STDF) in cooperation with The Egyptian Knowledge Bank (EKB).

Data availability The data underlying this article will be shared on reasonable request to the corresponding author.

\section{Declarations}

Disclosures None.

Open Access This article is licensed under a Creative Commons Attribution 4.0 International License, which permits use, sharing, adaptation, distribution and reproduction in any medium or format, as long as you give appropriate credit to the original author(s) and the source, provide a link to the Creative Commons licence, and indicate if changes were made. The images or other third party material in this article are included in the article's Creative Commons licence, unless indicated otherwise in a credit line to the material. If material is not included in the article's Creative Commons licence and your intended use is not permitted by statutory regulation or exceeds the permitted use, you will need to obtain permission directly from the copyright holder. To view a copy of this licence, visit http://creativecommons.org/licenses/by/4.0/. 


\section{References}

1. Hatemi G, Seyahi E, Fresko I, Talarico R, Hamuryudan V (2016) One year in review 2016: Behçet's syndrome. Clin Exp Rheumatol 34(Suppl. 102):S10-22

2. Hatemi G, Seyahi E, Fresko I, Talarico R, Hamuryudan V (2017) One year in review 2017: Behçet's syndrome. Clin Exp Rheumatol 35(Suppl. 108):S3-15

3. Colburn NT (2012) Review of rheumatology. SpringerVerlag London Limited. 417-430. https://doi.org/10.1007/ 978-1-84882-093-75

4. Gheita TA, El-Latif EA, El-Gazzar II, Samy N, Hammam N, A Abdel Noor R. et al (2019) Behçet's disease in Egypt: a multicenter nationwide study on 1526 adult patients and review of the literature [published correction appears in Clin Rheumatol. 38(9):2565-2575

5. Sakane T, Takeno M, Suzuki N, Inaba G (1999) Behçet's disease. N Engl J Med 341:1284-1291

6. Mizushima Y (1988) Recent research into Behçet's disease in Japan. Int J Tissue React 10:59-65

7. Davatchi F, SadeghiAbdollahi B, Chams-Davatchi C, Shahram F, Shams H, Nadji A et al (2015) The saga of diagnostic/classification criteria in Behcet's disease. Int J Rheum Dis 18:594-605

8. Davatchi F, Assaad-Khalil TS, Calamia KT, Crook JE, SadeghiAbdollahi B, Schirmer M, et al. The International Criteria for Behçet's Disease (ICBD): a collaborative study of 27 countries on the sensitivity and specificity of the new criteria. J Eur Acad Dermatol Venereol: JEADV. 28. https://doi.org/10.1111/jdv. 12107.2013

9. Piga M, Mathieu A (2011) Genetic susceptibility to Behcet's disease: role of genes belonging to the MHC region. Rheumatology 50:299-310

10. Gul A (2014) Genetics of Behcet's disease: lessons learned from genome wide association studies. Curr Opin Rheumatol 26:56-63

11. Chambers JC, Haskard DO, Kooner JS (2001) Vascular endothelial function and oxidative stress mechanisms in patients with Behçet's syndrome. J Am Coll Cardiol 37:517-520

12. Ambrose N, Khan E, Ravindran R, Lightstone L, Abraham S, Botto $\mathrm{M}$ et al (2015) The exaggerated inflammatory response in Behcet's syndrome: identification of dysfunctional post-transcriptional regulation of the IFN-gamma/CXCL10 IP-10pathway. Clin Exp Immunol 181(3):427-433

13. Cheon JH, Kim WH (2015) An update on the diagnosis, treatment, and prognosis of intestinal Behçet's disease. Curr Opin Rheumatol 27(1):24-31

14. Navarro M, Cervera R, Font J, Reverter JC, Monteagudo J, Escolar G et al (1997) Anti-endothelial cell antibodies in systemic autoimmune diseases: prevalence and clinical significance. Lupus 6:521-526

15. Praprotnik S, Blank M, Meroni PL, Rozman B, Eldor A, Shoenfeld Y (2001) Classification of anti-endothelial cell antibodies into antibodies against microvascular and macrovascular endothelial cells: the pathogenic and diagnostic implications. Arthritis Rheum 44:1484-1494

16. Aydintug AO, Tokgoz G, DÇruz DP, Gurler A, Cervera $\mathrm{R}$, Duzgun N et al (1993) Antibodies to endothelial cells in patients with Behçet's disease. Clin Immunol Immunopathol. 67:157-162

17. Cervera R, Navarro M, Lopez-Soto A, Cid MC, Font J, Esparza $\mathrm{J}$ et al (1994) Antibodies to endothelial cells in Behçet's disease: cell-binding heterogeneity and association with clinical activity. Ann Rheum Dis 53:265-267
18. Mor F, Weinberger A, Cohen IR (2002) Identification of alphatropomyosin as a target self-antigen in Behcet's syndrome. Eur J Immunol 32(2):356-365

19. Lee KH, Chung HS, Kim HS, Oh SH, Ha MK, Baik JH et al (2003) Human alpha-enolase from endothelial cells as a target antigen of anti-endothelial cell antibody in Behcet's disease. Arthritis Rheum 48(7):2025-2035

20. Ooka S, Nakano H, Matsuda T, Okamoto K, Suematsu N, Kurokawa MS et al (2010) Proteomic surveillance of autoantigens in patients with Behcet's disease by a proteomic approach. Microbiol Immunol 54(6):354-361

21. Keller M, Spanou Z, Schaerli P, Britschgi M, Yawalkar N, Seitz $M$ et al (2005) T cell-regulated neutrophilic inflammation in autoinflammatory diseases. J Immunol 175(11):7678-7686

22. Yoshioka T, Kurokawa MS, Sato T, Nagai K, Iizuka N, Arito M et al (2014) Protein profiles of peripheral blood mononuclear cells as a candidate biomarker for Behcet's disease. Clin Exp Rheumatol 32(4 Suppl 84):S9-19

23. Cho SB, Lee JH, Ahn KJ, Cho S, Park YB, Lee SK et al (2010) Identification of streptococcal proteins reacting with sera from Behcet's disease and rheumatic disorders. Clin Exp Rheumatol 28(4Suppl 60):S31-38

24. Janke C (2014) The tubulin code: molecular components, readout mechanisms, and functions. J Cell Biol 206:461-472

25. Fagerberg L, Hallström BM, Oksvold P, Kampf C, Djureinovic D, Odeberg J et al (2014) Analysis of the human tissue-specific expression by genome-wide integration of transcriptomics and antibody-based proteomics. Mol Cell Proteomics 13(2):397-406

26. Goers TA, Ramachandran S, Aloush A, Trulock E, Patterson GA, De MT (2008) novo production of K- $\alpha 1$ tubulin specific antibodies: role in chronic lung allograft rejection. J Immunol 180:4487-4494

27. Hachema RR, Tiriveedhib V, Pattersonc G, Aloush A, Trulock EP, Mohanakumar T (2012) Antibodies to K- $\alpha 1$ tubulin and collagen $\mathrm{V}$ are associated with chronic rejection after lung transplantation. Am J Transplant 12(8):2164-2171

28. International team for the revision of international criteria for Behçet's disease (2008) Clinical manifestations of for Behçet's disease The ITR-ICBD report. Clin Exp Rheumatol 26(Suppl 50):S1-S18

29. Ozdemir M, Balevi S, Deniz F, Mevlitoğlu I (2007) Pathergy reaction in different body areas in Behçet's disease. Clin Exp Dermatol 32:85-87

30. Neves FD, Caldas CM, de Medeiros DM, de Moraes JB, Gonçalves CR (2009) Cross-cultural adaptation of simplified version (s) of Behçet's Disease Current Activity Form (BDCAF) and comparison between two different instruments with Brazilian versions for evaluating Behçet's disease activity: BR-BDCAF and BR-BDCAF (s). Rev Bras Reumatol 49(1):20-31

31. Luqmani RA, Bacon PA, Moots RJ, Janssen BA, Pall A, Emery $P$ et al (1994) Birmingham Vasculitis Activity Score (BVAS) in systemic necrotizing vasculitis. QJM 87:671-678

32. Pineton De Chambrun M, Wechsler B, Geri G, Cacoub P, Saadoun D (2012) New insights into the pathogenesis of Behcet's disease. Autoimmun Rev 11(10):687-698

33. Cheng Y, Zhao X, Chen Y, Li Y, Jia R, Zhu L et al (2018) Circulating immune complexome analysis identified antitubulin- $\alpha-1 \mathrm{c}$ as an inflammation associated autoantibody with promising diagnostic value for Behcet's disease. PLoS ONE. 13(6): 0199047

34. Dinc A, Takafuta T, Jiang D, Melikoglu M, Saruhan-Direskeneli G, Shapiro SS (2003) Anti-endothelial cell antibodies in Behcet's disease. Clin Exp Rheumatol 21(4 Suppl. 30):S27-S30

35. Zheng WJ, Zhao Y, Tang FL, Dong YY (2005) A study of antiendothelial cell antibodies in Behcet's disease. Zhonghua Nei Ke Za Zhi 44(12):910-913 
36. Avrameas S, Guilbert B, Dighiero G (1981) Natural antibodies against tubulin, actin myoglobin, thyroglobulin, fetuin, albumin and transferrin are present in normal human sera and monoclonal immunoglobulins from multiple myeloma and Waldenström's macroglobulinemia may express similar antibody specificities. Ann Immunol (Paris) 132C:231-236

37. Dighiero G, Guilbert B, Avrameas S (1982) Naturally occurring antibodies against nine common antigens in humans' sera. II. High incidence of monoclonal Ig exhibiting antibody activity against actin and tubulin and sharing antibody specificities with natural antibodies. J Immunol 128:2788-2792

38. Kurki P, Virtanen I (1984) The detection of human antibodies against cytoskeletal components. J Immunol Methods 67:209-223

39. Newcombe J, Gahan S, Cuzner ML (1985) Serum antibodies against central nervous system proteins in human demyelinating disease. Clin Exp Immunol 59:383-390

40. Rousset B, Bernier-Valentin F, Poncet C, Orgiazzi J, Madec AM, Monier JC (1983) Mornex R Anti-tubulin antibodies in autoimmune thyroid disorders. Clin Exp Immuno. 152: 325-332

41. Shaker O, Ay El-Deen MA, El Hadidi H, Grace BD, El Sherif H, Abdel Halim A et al (2007) The role of heat shock protein 60, vascular endothelial growth factor and antiphospholipid antibodies in Behcet disease. Br J Dermatol 156(1):32-37

42. Balta I, Balta S, Koryurek OM, Demirkol S, Mikhailidis DP, Celik T et al (2014) Serum endocan levels as a marker of disease activity in patients with Behcet's disease. J Am Acad Dermatol 70:291-296

43. Yoshio T, Masuyama J, Sumiya M, Minota S, Kano S (1994) Anti-endothelial cell antibodies and their relation to pulmonary hypertension in systemic lupus erythematosus. J Rheumatol 21:2058-2063

44. Goers TA, Ramachandran S, Aloush A, Trulock E, Patterson GA, Mohanakumar T et al (2008) De novo production of K-alpha1 tubulin-specific antibodies: role in chronic lung allograft rejection. J Immunol 180(77):4487-4494

45. Aylett CH, Lowe J, Amos LA (2011) New insights into the mechanisms of cytomotive actin and tubulin filaments. Int Rev Cell Mol Biol 292:1-71

Publisher's note Springer Nature remains neutral with regard to jurisdictional claims in published maps and institutional affiliations. 